\title{
Impact of Servicescape on Customer Patronage of Fuel Stations in Abia State, Nigeria
}

\author{
Onuoha A. Onuoha PhD, Nnenanya Doris \\ Department of Marketing, University of Port Harcourt, Port Harcourt, Nigeria
}

\begin{abstract}
This study examined the impact of servicescape on customer patronage of fuel stations in Abia State, Nigeria. Questionnaire was used to generate data from 450 respondents drawn from 30 fuel stations selected from three major cities of the State. Three hypotheses formulated for the study were tested using pearson's product moment correlation coefficient. Results showed that all three dimensions of servicescape used in the study have significant impact on customer patronage. The implication of the study is that fuel stations should, as a matter of policy, treat servicescape as an essential marketing strategy that should be better managed for sustainable customer patronage and profitability.
\end{abstract}

Keywords: Servicescape, Customer Patronage, Fuel Stations, Abia State, Nigeria.

\section{INTRODUCTION}

Nigeria's downstream oil sector (subsequently referred to as "the downstream") is highly regulated (Ibanga, 2009; Sanusi, 2011; Wogu, 2011; Sokubi, 2011; Ogwo \& Onuoha, 2013). The downstream is a set of participants (including their activities) engaged in ensuring the availability of petroleum products from refineries and import points to the end users (Okpara \& Anyanwu, 2006).

Government had at various times, including 2012 and 2016, tried to liberalize the activities of the downstream. The goal of government in adopting the principles of liberalization of the downstream is influenced by the successes of other countries in doing same. However, at issue is the stiff resistance which the policy has encountered from the organized labour, thus making it sounds like a "hard sell" (Ogwo \& Onuoha, 2013).

As the debate of the deregulation of the downstream persists, government for now is still the highest decision-maker as long as marketing of petroleum products in Nigeria is concerned, including allocation, pricing and distribution of these products. This scenario has virtually made competition, especially based on marketing's 4Ps - product, price, promotion and place - unfashionable for the downstream, as their offers are "commodities" (not products) without clear brand identity and loyalty, sold at uniform prices which none of them can justify a unilateral change in the prices, physically or psychologically (Okpara \& Anyanwu, 2006), in promotion.

Nevertheless, the downstream still strive to attract customer patronage, especially as they concentrate their sales outlets, popularly known in Nigeria as "Filling Stations", at major roads of a particular town. They do this by resorting to service-based competition. Thus, the downstream use productaccompanying services as means of attracting customers to their fuel stations. The outward appearance of these services, referred to as servicescape (Anand, 2008), plays essential role in influencing the nature of customer experiences (Bitner, 1992) as well as in forming initial impression on customer expectations (Anand, 2008). Since the downstream offer uniform products, at uniform prices, any perceived evidence of an eventual "quality" of the accompanying intangible service, that is servicescape (Berry \& Parasuraman, 1991), would be an added advantage for the downstream concerned, and thus improve customer patronage. This study, therefore, seeks to find out if servicescape has any impact on customer patronage of fuel stations in Nigeria, with particular reference to Abia State.

\section{LiterATURE REVIEW}

\subsection{Servicescape}

Servicescape, as defined by Namasivayam and Lin (2008), is the physical environment of a firm, including the overall layout, design and decoration. It is also the built environment, with an artificial 
physical surrounding as opposed to the nature or social environment (Bitner, 1992). Servicescape is more profound in firms that offer core services, like hotels, hospitals, cinemas and schools, yet its importance cannot be over emphasized in firms where customer services are rendered, as effective manipulation of the servicescape can lead to customer satisfaction and increase repeat purchases (Namasivayam \& Lin, 2008). Thus, servicescape is important in both firms because of its influences on consumers' behavior (Bitner, 1992; Namasivayan \& Lin, 2008). However, firms should be careful about their servicescape, as it is capable of enhancing or suppressing consumers' emotions (Kwabena et al, 2011).

A number of researchers and authors have suggested various dimensions of servicescape. The dimensions of servicescape as suggested by Bitner (1992) are ambient conditions, spatial layout and functionality, and signs, symbols and artifacts. For Namasivayam and Lin (2008), the dimensions include overall layout, design, décor and atmospherics. This study adopts Bitner's three - dimension model of servicescape with an adjustment - removal of signs, symbols and artifacts and addition of staff attitude. This is our point of departure. The adjustment was predicated on our preliminary discovering that all the fuel stations selected for study do not have much signs, symbols and artifacts except arrors indicating Entry (IN) and Exit (OUT). Thus, the dimensions used in this study are ambient conditions, spatial layout and staff attitude.

\subsection{Ambient Conditions}

Ambient conditions have been identified by numerous authors, including Baker (1987), Chebat et al (2001), Varley (2006), Levy and Weitz (2007) and Broekemier et al (2008), as essential elements that affect human perceptions of and responses to an environment. Ambient conditions are the background features of an environment, and include elements like temperature, lighting, noise, music and scent, which mostly affect the five senses (Kwabena et al, 2011).

Ambient conditions are used by customers as part of auditory components of their evaluations of an environment, whereas management can use them as effective tools to reduce the negative consequences of waiting in any service operation (Hui et al, 1997). In view of the foregoing, ambient conditions have been affirmed as influential factors on customer responses (Milliman, 1982, 1986; Hui et al, 1997; Broekemier et al, 2008).

\subsection{Spatial Layout}

Fuel stations render some meaningful services while selling the physical products. As such, spatial layout of the physical surroundings should not be left to change, as it is one essential determinant factor of consumer loyalty to a particular firm (Russel \& Ward, 2000). Spatial layout is the design and arrangement of services equipments, including the provision of space among them for easy movement (Wakefield \& Blodgett, 2005). The comfortability of a customer in a service point depends much on the spatial layout of the physical surrounding (Awasthi \& Suvivastava, 2014). The amount of space between two opposite fuel dispensing pumps is an important dimension of spatial layout of a fuel station, as it affects the ease with which vehicles may enter and exit the station. If the space is too narrow, attending to two vehicles will be difficult, thus causing unnecessary delay which customers frown at (Guy \& Duckett, 2003).

\subsection{Staff Attitude}

Attitude is a set of enduring psychological processes with respect to some aspects of our environment (Hawkins et al, 2001). Thus, the way one thinks, feels and acts toward some aspects of one's environment forms the person's attitude (Tiapana, 2009). A given object in the environment upon which one predisposes his attitude may include television or radio programme, person, product, profession, firm or a retail store.

In view of the foregoing, Baker (1987) highlighted three environmental factors - ambient cues, design cues and social cues - that could impact positively on customers' attitude toward a store and increase the chances to purchase more. Nadia and Zekeriya (2013) are of the opinion that social cues are based on customer employee interaction which highly influences customer perception about the store.

The success of the interactions among customers and employees depends on the staff attitude, which Little and Dean (2006) defined as employees' commitment towards the goals and aspirations of an organization, including their willingness to maintain membership of the organization. Thus, positive 
staff attitude, expressed verbally and non-verbally during customer-employee interactions, is an important factor in creating lasting impression that affects satisfaction, repeat purchase and profitability (Brown \& Lam, 2008).

\subsection{Customer Patronage}

Customer patronage is a combination of psychological factors that influences purchase behaviour (Burnkrant, 1982); and these factors are considered important by consumers (Moye \& Giddings, 202); and used as yardsticks in determining which firm to patronize (Ogbuji et al, 2016).

Customer patronage has been measured by various authors in different dimensions, including store traffic flow (Engle et al, 1996); willingness, word-of-mouth and repurchase (Baker et al, 2002); repeat purchase, customer retention and customer referrals (Awah, 2015); and customer satisfaction and referrals (Ogbuji et al, 2016). These dimensions of customer patronage were used against different marketing phenomena. Nevertheless, the phenomenon in focus in this study is servicescape.

In view of the foregoing, the theoretical framework, as shown in figure 1, was developed; and the following hypotheses derived there from.

$\mathrm{H}_{1}$ : Ambient conditions have significant impact on customer patronage.

$\mathrm{H}_{2}$ : Spatial layout has significant impact on customer patronage.

$\mathrm{H}_{3}$ : Staff attitude has significant impact on customer patronage.

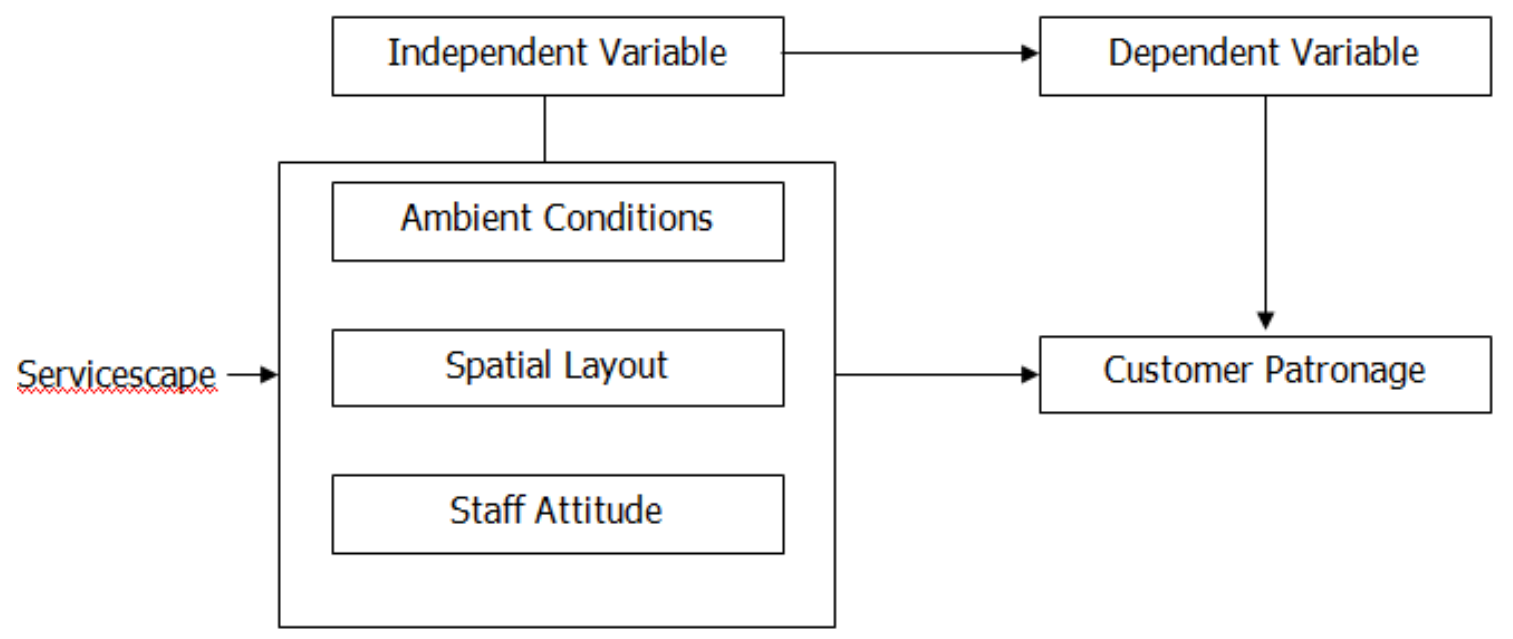

Figure1. Theoretical Framework of the Present Study

\section{RESEARCH Methodology}

This study was carried out in Abia State, Nigeria. The State is divided into three (3) Senatorial Zones - Abia North, Abia Central and Abia South. Data used in the study were mainly sourced using a set of questionnaire distributed to 450 participants drawn from the three zones, on the basis of 150 per zone. The participants were selected from 10 Fuel Stations in each of the three zones (total 30), on the basis of 15 per Fuel Station. However, elements that constituted the sample size were those seen buying or queued to buy one petroleum product or the other. Thus, convenience sampling was used in the study (Ezejelue et al, 2008).

All copies of the questionnaire were completed and returned, as the researchers prevailed on the participants to fill the questionnaire at the spot. The questionnaire contained items that were relevant to the variables being measured. Participants were asked to rate each item using a 5-point Likert Scale of Strongly Disagree (1), Disagree (2), Neutral (3), Agree (4) and Strongly Agree (5). The questionnaire was pilot tested on 30 participants drawn from two fuel stations in Umuahia - the State's capital, and a town in Abia Central Zone. Cronbach's alpha coefficient of ambient conditions, spatial layout, staff attitude and customer patronage, as shown in Table 1, was 0.751, 0.766, 0.772 and 0.763, respectively; thus exceeding the 0.7 recommended by Nunnally (1978). These figures confirmed the reliability of the study's instrument. Pearson's Product Moment Correlation Coefficient (r) was used in testing the hypotheses. 
Onuoha A. Onuoha \& Nnenanya Doris

Table1. Reliability Results

\begin{tabular}{|l|l|l|l|l|l|c|}
\hline \multicolumn{1}{|c|}{ Variables } & \multicolumn{1}{c|}{ Mean } & Standard Deviation & \multicolumn{1}{c|}{$\mathbf{1}$} & $\mathbf{2}$ & $\mathbf{3}$ & $\mathbf{4}$ \\
\hline Ambient conditions & 3.32 & 1.801 & $(0.751)$ & & & \\
\hline Spatial layout & 3.71 & 1,783 & $0.745^{* *}$ & $(0.766)$ & & \\
\hline Staff attitude & 3.26 & 1.239 & $0.698^{* *}$ & $0.771^{* *}$ & $(0.772)$ & \\
\hline Customer patronage & 3.55 & 1.499 & $0.687^{* *}$ & $0.815^{* *}$ & $0.817^{* *}$ & $(0.763)$ \\
\hline
\end{tabular}

**Correlation is significant at the 0.01 level (2-tailed) Reliability Cronbach's Alpha ( $\alpha)$ in parenthesis

\section{Results AND Discussion}

Tables 2, 3, and 4 show the results of the test of hypotheses 1, 2 and 3 respectively, using Pearson's Product Moment Correlation Coefficient.

Table2. Correlation Result for Ambient Conditions

\begin{tabular}{|l|l|l|l|}
\hline & & \multicolumn{1}{|c|}{ Ambient Conditions } & Customer Patronage \\
\hline Ambient Conditions & Pearson correlation & 1 & $.908^{* *}$ \\
& Sig. (12-tailed) & & .000 \\
& $\mathrm{~N}$ & 450 & 450 \\
\hline Customer Patronage & Pearson correlation & $.908^{* *}$ & 1 \\
& Sig. (2-tailed) & .000 & \\
& $\mathrm{~N}$ & 450 & 450 \\
\hline
\end{tabular}

**Correlation is significant at the 0.01 (2-tailed)

Table 2 shows that ambient conditions have significant impact on customer patronage, with $r=0.908$ and $\mathrm{p}<0.01$. This result supports $\mathrm{H}_{1}$. The implication of the result is that improvement in ambient conditions leads to increase in customer patronage. This finding is in line with the findings of Namasivayam and Lin (2008) and Kwabena et al (2011) that a firm's ambience significantly influences customer patronage.

Table 3 shows that spatial layout has significant impact on customer patronage, with $r=0.938$ and $p<$ 0.01 , thus supporting $\mathrm{H}_{2}$, and indicating that an improved spatial layout would lead to increase in customer patronage. Other studies that support this finding include Ogbuji et al (2016), and Wakefield and Blodgett (2005).

Table3. Correlation Result for Spatial Layout

\begin{tabular}{|l|l|l|l|}
\hline & & \multicolumn{1}{|c|}{ Spatial Layout } & \multicolumn{1}{|c|}{ Customer Patronage } \\
\hline Spatial Layout & Pearson correlation & 1 & $.938^{* *}$ \\
& Sig. (2-tailed) & & .000 \\
& $\mathrm{~N}$ & 450 & 450 \\
\hline Customer Patronage & Pearson correlation & $.938^{* *}$ & 1 \\
& Sig. (2-tailed) & .000 & \\
& $\mathrm{~N}$ & 450 & 450 \\
\hline
\end{tabular}

**Correlation is significant at the 0.01 (2-tailed)

A glance at Table 4 shows that $\mathrm{H}_{3}$ is supported, with $\mathrm{r}=0.941$ and $\mathrm{p}<0.01$, implying that staff attitude has significant impact on customer patronage. This result indicates that friendly and empathetic employees are great assets to increase in customer patronage. The finding is in line with the findings of Schneider et al (2003) and Brown and Lam (2008).

Table4. Correlation Result for Staff Attitude

\begin{tabular}{|l|l|l|l|}
\hline & & \multicolumn{1}{|c|}{ Staff Attitude } & \multicolumn{1}{|c|}{ Customer Patronage } \\
\hline Staff Attitude & Pearson correlation & 1 & .941 \\
& Sig. (2-tailed) & & .000 \\
& $\mathrm{~N}$ & 450 & 450 \\
\hline Customer Patronage & Pearson correlation & .941 & 1 \\
& Sig. (2-tailed) & .000 & \\
& $\mathrm{~N}$ & 450 & 450 \\
\hline
\end{tabular}

**Correlation is significant at the 0.01 (2-tailed) 


\section{CONCLUSION AND IMPLICATION}

All three dimensions of servicescape used in this study were found to have positive significant impact on customer patronage. This obviously shows that improved servicescape impact significantly on customer patronage. Thus, issues that concern adequacy of a firm's servicescape should not be left to chance, if improved and sustained customer patronage is desired. Managers of Fuel Stations, and indeed other retail outlets, are advised to treat servicescape as an essential marketing strategy that should, as a matter of policy, be better managed for sustainable customer patronage and profitability.

\section{REFERENCES}

Anand, L. (2008). A study of the impact of servicescape, emotions, behaviors, and repatronage intentions in upscale restaurants - Mumbai. University of Huddersfield, UK.

Awah, C. K. (2015). Store layour and customer patronage of supermarkets in Port Harcourt. University of Port Harcourt, Nigeria.

Awasthi, K. A. \& Shrivastava, A. (2014). Servicescape elements in leisure service settings. International Journal of Hospitality and Tourism System, 69-73.

Baker, J. (1987). The role of environment in marketing services: The consumer perspective. In Czpeil, J. A., Congram, C., \& Shanaham, J. (eds). The Services Marketing Challenge: Integrated for Competitive Advantage. Chicago: American Marketing Association; 79-84.

Baker, J., Grewel, D., Parasuraman, A. \& Voss, G. B. (2002). The influence of multiple store environment cues on perceived merchandise value and patronage intentions. Journal of Retailing, 79: 259-268.

Berry, L. L. \& Parasuraman, A. (1991). Marketing Services: Competition through Quality. New York: Free Press.

Bitner, M. J. (1992). Servicescape: The impact of physical surroundings on customers and employees. Journal of Marketing, 56:69-82.

Broekemier, G., Marquardt, R. \& Gentry, J. W. (2008). An exploration of happy/sad and liked/disliked music effects on shopping intentions in women's clothing store service setting. Journal of Services Marketing, 22 (1): 50-67.

Brown, S. P. \& Lam, S. K. (2008). A meta-analysis of relationships linking employee satisfaction to customer responses. Journal of Retailing, 84 (3): 243.

Burnkrant, R. (1982). An examination of the convergent, discriminant and predictive validity of Fishbein's Behavioural Intention Model. Journal of Marketing Research, 19 (4).

Chebat, J. C., Chebat, C. G. \& Vaillant, D. (2001). Environmental background music and in-store selling. Journal of Business Research, 54 (2): $115-123$.

Engel, J. F., Blackwell, R. \& Miniard, P. (1996). Consumer Behaviour. New York: Dryden Press.

Ezejelue, A. C., Ogwo, E. O. \& Nkamnebe, A. D. (2008). Basic Principles in Managing Research Projects, $2^{\text {nd }}$ ed. Aba: Afritowers.

Guy, C. and Duckett, M. (2003). Small retailers in an inner city community: A case study of Adamsdown, Cardiff. International Journal of Retail and Distribution Management, 31 (8): 401407.

Hawkins, D. L., Mothersbaugh, D. L. \& Best, R. J. (2001). Consumer Behaviour: Building Marketing Strategy, $10^{\text {th }}$ ed. New York: McGraw-Hill.

Hui, M. K., Dube, L. \& Chebat, J. (1997). The impact of music and consumers' reactions to waiting for services. Journal of Retailing, 73: 87-104.

Ibanga, I. (2009). The economics of privatizing and deregulating the Nigerian downstream oil sector (online). Available: www.florin.com/valore/ifikibanga.html (January 27, 2012).

Kwabena, N. S., Mabel, S., Inusah, A. \& Kwesi, A. (2011). Servicescape and customer patronage of three-star hotels in Ghana's Metropolitan City of Accra. European Journal of Business and Management, 3(4):119-131.

Levy, M. \& Weitz, B. A. (2007). Retail Management, $7^{\text {th }}$ ed. New York: McGraw-Hill.

Little, W. M. \& Dean, A. M. (2006). Links between service climate, employee commitment and employees' service quality capability. Managing Service Quality, 16 (5): 460-476. 
Milliman, R. E. (1982). Using background music to affect the behavior of supermarket shoppers. Journal of Marketing, 46: 86-91.

Milliman, R. E. (1986). The influence of background music on the behavior of restaurant patrons. Journal of Consumer Research, 286-289.

Moye, L. N. \& Giddings, V. I. (2002). An examination of the retail approach - avoidance behavior of older apparel consumers. Journal of Fashion Marketing and Management, 6 (3): 259 - 276.

Nadia, S. \& Zekeriya, N. (2013). Impact of customer relationship on customer loyalty in cellular industry: Evidence from Kak, Pakistan. Asian Journal of Management Sciences \& Education, 2 (3): 20-30.

Namasivyam, K. \& Lin, I. (2008). The servicescape. In Jones, P. (ed). The Handbook of Hospitality Operation and IT. New York: Elsevier Publishers.

Nunnally, J. C. (1978). Psychometric Theory. $2^{\text {nd }}$ ed. New York: McGraw-Hill.

Ogbuji, C. N., Onuoha, A. O. \& Abdul, U. (2016). Spatial layout and customer patronage of cinema firms in Port Harcourt, Nigeria. International Journal of Research in Business Studies and Management, 3 (6): 44-50.

Ogwo, E. O. \& Onuoha, A. O. (2013). The imperative of marketing in the management of deregulation: A study of the Nigerian downstream oil sector. Asian Journal of Management of Science and Education, 2(3): 1-10.

Okpara, G. S. \& Anyanwu, A. (2006). The changing face of marketing management in a deregulation downstream oil sector. Journal of Business and Social Sciences, 2 (2): 87-93.

Russel, J. \& Ward, I. (2000). Environmental Psychology. Annual Review of Psychology, 33(1).

Sanusi, L. S. (2011). Why Nigeria must deregulate. Daily Sun, Monday, December 12.

Sokunbi, W. (2011). The bumpy road to fuel subsidy. Daily Sun, Monday, December 12.

Tiapana, T. P. (2009). Store layout and its impact on consumer purchasing behavior at convenience stores in Kwa Mashu. Durban University of Technology.

Varley, R. (2006). Retail Product Management: Buying and Merchandising, $2^{\text {nd }}$ ed. New York: Routledge.

Wakefield, L. K. \& Blodgett, G. J. (2005). The importance of servicescape in leisure service settings. Journal of Services Marketing, 5(6).

Wogu, E. (2011). Why subsidy must go. Daily Sun, Monday, December 12. 